\title{
Rain Forest or Metropolis: Brazilian Modernists' Debate Between the Local and the Global in Literature
}

In this article the relationship between world literature and national literature in its Brazilian context will be analysed. In the first part the Brazilian intellectual debate during the first three decades of the 20th century will be shortly introduced, especially as it was centered around the questions of nationalism and globalism. In the second part I will bring some examples related to the mentioned topics from some texts written by two top Brazilian modernist authors Oswald and Mario de Andrade. During the development of my argument I will give some examples from other periods as well. I shall also focus on the concept of the 'wild man' which was formed in Europe and imported to Brazil. The purpose of the article is to criticise the existing tradition of defining a global literary movement and propose an alternative approach on the example of Brazilian modernism.

The tension between 'own' and 'foreign', 'local' and 'global', 'central' and 'peripheric' was the main topic in the intellectual debate in Brazil of the 1910s and the 1920s - the high tide of modernism. There were strong supporters of both leading cultural models: cosmopolitan and nationalist thinking.

The birthplace and later center of Brazilian modernism was the city of São Paulo. São Paulo of the 1910s-20s was perhaps even more fit and ready for modernism than any European city of the period: the growth, the modernisation, urbanisation and immigration processes were extremely intense. The numbers of immigrants from Europe, as well as those of internal immigration from the poor, mostly rural areas of Brazil were very big. At the same time São Paulo was culturally frozen, the literary norms were outdated and the fastest growing city was lacking any cultural interest. "In Brazil, the area where the conflict between provincial / urban was felt most sharply was São Paulo." (Bosi 2003: 209) 
PESTI

Richard Morse in his well-wrought cultural history of São Paulo notes the "intellectual apathy" of paulistas as the whole state was concentrated on the stir of the material progress (Morse 1954: 423). There was an obvious need for new ideas to enter, but simultaneously there was a strong opposition to the previous European cultural models that had been forming the literary scene in the previous centuries. This protest transforms into the fight of young Brazilian modernists against the Brazilian literary academy.

Brazilian cultural historians (cf. Brito 1971) describe São Paulo at the beginning of the 1920s as having an ultranationalist and at times xenophobic atmosphere. Everybody was waiting for the advent of the centenary of Brazilian independence in 1922 (ib. 138). In 1921 there were heated discussions in the media about nationalism, with the young modernist writers Oswald de Andrade, Mario de Andrade and Menotti del Picchia in the forefront. Modernists were not directly connected to the nationalists, but their program of developing the Brazilian language and stressing the differences from the European Portuguese was also quite political (ib. 140).

The main literary discussion of the time relates directly to positioning Brazilian national literature within the world literature and also vice versa: positioning the worldly impacts inside the national scene. The dynamics of influences between these two poles is far more complex than is often imagined. In a cultural situation with high levels of hybridity - as is the case of Brazil - our traditional way to distinguish between the outside and the inside, the worldly and the national can sometimes lack explanatory power.

Any fair debate about world literature and the position of a national literature within it cannot escape the axis of center-periphery. In this respect Brazil holds the roll of periphery, though in many other aspects, of course, Brazil is surely not a peripheral country, becoming more and more central in our contemporary world. But in the World Republic of Letters it still has the peripheral status due to different barriers, for example the linguistic ones. Brazilian literature was even more confined to this peripheral status during the periods discussed in this article.

It would be a simplification to just say that world literature is the sum of the more noteworthy parts of the national literatures of the whole world. The structuring normative forces have an enormous silent role in the decisions of what enters the canon (both on the global and perhaps less obviously also on the local level). Even if there exists a debate about the willingness to accept foreign literary norms within a peripheral country (and usually such a debate and perhaps some form of resistance to foreign norms exists), these norms are 
still forming the grid of the value-making processes within the local cultural establishments.

We tend to assume that new literary norms or fashions are born somewhere (usually center) and after a while they are to some extent copied or imitated in many other places (usually periphery). For example the literary movement 'Modernism' consists of certain cultural movements originating from Europe (mostly Paris or London) that had later weaker rebounds in some of the border areas of Europe and outside Europe. Thus, according to this common logic, Brazilian, Argentinian, Nicaraguan, etc, modernisms are automatically seen as fading copies of the original. They are supposed to be the peripheral expressions of a central blast.

The central argument of this article is that we should not conceptualize one literary movement as only what it was in its birthplace, at the time and location of its most famous authors, having later weaker rebounds in peripheries. Even if this, to many readers, may sound as an extremely conservative view, a fight which was fought a long time ago, it is actually still the way how literature is mostly taught at high schools worldwide.

The proposal that needs promoting instead would be to research all the local "variations" of any literary movement, letting go of the normative opposition between the original and the copies and apply full methodological power to researching these new forms born in the periphery - keeping in mind their possible potential of being different and even richer than the so-called 'original'. Yuri Lotman stated in his famous article "On Semiosphere", that boundary is "the area of accelerated semiotic processes, which always flow more actively on the periphery of cultural environments, seeking to affix them to the core structures, with a view of displacing them." (Lotman 2005: 205) In the first phase of reforming the idea of the world literary canon I would suggest not to displace the creations that have come from the core - these processes happen on their own if they need to happen. But what is found from periphery should definitely be added to the original concept of a literary movement without the inside hierarchical distinction of before and after, original and copy.

In the context of modernism the principle idea of re-defining the canon could be:

1) The way it is still being defined: Modernism is something that happened in Europe, mostly Paris and London. After the full stop there might come, in small letters, a mention of attempts of copying some parts of modernism here and there in the periphery. 
PESTI

2) The proposed new way of seeing it: Modernism is a global experience that includes the earlier attempts made in the centers of Europe and further developments of similar and different experiences in other parts of the world.

Now, this proposal might seem only ideological at first look, an attempt to be politically correct, to bring the weaker ones to the spotlight and give them more weight just because they come from the 'periphery'. But the reasoning behind this idea does not run in this line at all. Of course we have to keep on weighing carefully the literary value of the works to see if the potential of new added value and richness from periphery is bearing fruit or not in each specific example. Continuing in a bit speculative direction: perhaps there is a point on the road of maturing for each specific national literature, where we can detect the shift from definition $\mathrm{nr} 1$ to definition $\mathrm{nr} 2$. That's when a new value, a change, a new interesting form adds to the central model.

Coming back to the Brazilian example: the Brazilian scholar Roberto Schwarz has shown well in his essays (the English translation 'Misplaced Ideas' 1992) where this line runs in literary history. He analyzes Brazilian Romanticism, mainly its most famous prose author José de Alencar and shows the drawbacks of Alencar: the highly acclaimed author borrows the central protagonist's worldview from Balzacian France and adds other characters of mainly Brazilian colour. The protagonist's ideals, worries and fantasies tend not to make sense as projected to his contemporary Brazilian reality, as it was extremely different from French reality. This discordance created a strong sense of incompatibility, unnaturalness, producing even a comic effect (Schwarz 1992).

Moving then on to realism, Schwarz shows how Brazilian most famous realist author Machado de Assis actually did the same - combined characters with mindsets borrowed from the European model with the local Brazilian realities. But unlike Alencar, Machado de Assis was totally conscious of the innate discrepancy in the literary world he created, and so he used dark irony rising from that situation to make a comment about the reality around him. This discrepancy between the European and local ways of being, acting and thinking was part of Brazilian reality, it was present in everyday life where European norms were tried to be met, but on the meaning-formation bases they did not make sense at all. Machado de Assis managed to transform this tension into literary masterpieces (ib.).

Thus, allowing myself to be a bit schematic: in the case of Brazilian literature the passing from definition one to definition two of defining literary 
movements might have happened somewhere between Alencar and Machado de Assis. In the works of the leading romantic author there is an annoying discord between the imposed context and local reality and the result does not notably expand the boundaries of the canon of Romanticism. But the leading realist author used innovation and turned this discord into strength, into the original Brazilian experience of Realism. Perhaps starting from Machado de Assis the role of Brazilian national literature starts growing its relative part in the body of world literature.

Moving on along the timeline into the 20th century: here the Brazilian socio-historical experience is very original and its fruits in literary form add a lot to world literature. Most of the debate at the start of the 20th century Brazil was about letting world literature come in: should we follow the French madness of surrealism or the Italian utopia of futurism? Or should we instead turn more towards the tradition, find our Amazonian roots and define our difference?

Only in 1924 there rose a stronger voice putting on the public agenda the other part of the equation: the importance of taking Brazilian literature into the world. It was the modernist poet Oswald de Andrade who wrote a manifest called Manifesto Pau-Brasil - The Manifest of the Brazilwood. The name of the country comes from a tree called Brazil that had a high price on European markets and was thus very valuable for Portuguese colonizers. This meant that in the eyes of the colonizers the whole country was reduced to one line in their import accounts, Brazil was just some place from where to bring this product.

Oswald de Andrade makes a proposal to reverse this situation. Instead of crass copying of European models, the Brazilians should create a strong original culture which the whole world would want to get to know. Instead of cheap raw products Brazil should export its invaluable poetry and prose. For that purpose he invites his fellow writers to concentrate on the natural way of Brazilian contemporary being and transform it into poetry worth being introduced to the whole world.

A lingua sem arcaismos, sem erudição. Natural e neologica. A contribuição milionaria de todos os erros. Como falamos. Como somos. (...) Dividarnos: Poesia de importação. E a Poesia Pau-Brasil, de exportação. ${ }^{1}$ (An extract from Manifesto Pau-Brasil, De Andrade, 1924)

\footnotetext{
${ }^{1}$ Language without archaisms, without erudition. Natural and neologic. The millionaire-contribution of all the errors. The way we speak. The way we are. (...) Let's make a division: poetry of import. And Pau-Brazil (Brazilwood) Poetry, for exportation. (trans by Stella M. de Sa Rego)
} 
PESTI

The second important idea of the Manifesto Pau-brasil lies within the phrase "forest and school". Oswald invites the Brazilian poets to find subject matter in their nation, land, roots and nature, but before that to gasp the "school" part of the formula: the civilization, the better part of European inventions.

I will now give a few examples of this poetry for exportation offered by the same author. In the poem "Brasil" from the 1927 collection Primeiro caderno do aluno de poesia Oswald de Andrade (The First Exercise-book of the Poetry Student Oswald de Andrade) he re-interpreted the history of the colonial encounter - in contemporary terms we would say - in a post-modern way.

Brasil

O Zé Pereira chegou de caravela

E preguntou pro guarani da mata virgem

- Sois cristão?

- Não. Sou bravo, sou forte, sou filho da Morte

Teterê Tetê Quizá Quizá Quecê!

Lá longe a onça resmungava Uu! ua! uu!

O negro zonzo saído da fornalha

Tomou a palavra e respondeu

- Sim pela graça de Deus

Canhém Babá Canhém Babá Cum Cum!

E fizeram o Carnaval ${ }^{2}$

In "Brasil" the description of the encounter, the 500 years of history in the Western canon, the Christianization process with some resistance by the Indians and the main myth of Brazilian society consisting of the three happily joint races are quite originally and concisely woven into one short poem. The figure of Zé Pereira originates from Portugal, where a kind of a musical

Zé Pereira arrived on a caravel

And asked from a guarani in the virgin forest

Are you Christians?

No. I am brave, I am strong, I am the Son of Death

Teterê Tetê Quizá Quizá Quecê!

Back there a jaguar mumbled Uu! ua! uu!

A silly negro came out of the heat

took the word and answered:

-Yes, by God's grace

Canhém Babá Canhém Babá Cum Cum!

And they had a carnival.

(Transl by M.P) 
instrument has the same name, it is still used as a term in Brazilian carnival vocabulary. Zé Pereira arriving on a caravel certainly symbolizes the Portuguese colonizers who imported Christianity to the New World. The tupi guarani Indians tried to deny the new masters with new religion at first and restrained from the colonization process a while, but with the help of the Black slaves imported from Africa the Portuguese managed to take control of Brazil and force Christianity upon all its inhabitants. The successful hybridization process is celebrated by a symbolic joyous party, the legendary Brazilian Carnival, where the rich and the poor, the colonizer and the colonized forget their differences for a few nights. Still, the original elements, the roots of both Indian and Black culture are distinguishable within the mixture, symbolized by the two respective lines of linguistic heritage in "Brasil".

"Brasil" certainly withholds high levels of irony and mild criticism towards the foundation myth of contemporary Brazil. But its humour is very benevolent, it does not seem to suggest an alternative history. From his first poetry collection, written in 1925 (one year after publishing the Manifesto Pau-Brasil and two years before the Primeiro Caderno) in the poetry collection called Poesia Pau-Brasil, there is even a shorter poem that treats the same historical process - the encounter - but also offers a short sketch that might be read as the beginning of an alternative history.

Erro de português

Quando o português chegou

Debaixo duma bruta chuva

Vestiu o índio

Que pena! Fosse uma manhã de sol

O índio tinha despido

O português ${ }^{3}$

Mistake of the Portuguese

When the Portuguese arrived

It was raining like hell

He dressed the Indian in clothes.

What a shame!

If only it had been a sunny day

The Indian would have undressed

The Portuguese.

(Trans. by Flavia Vidal. Twentieth-century Latin American poetry: a bilingual anthology by

Stephen Tapscott, p. 93) 
PESTI

We could easily dismiss this poem by calling it some witty joke with a funny punchline having some erotic allusions as trivial anecdotes often do. But knowing the contents and the message of Manifesto Pau-Brasil and its more profound follow-up Manifesto Antropofago of 1928, it is difficult to do so. In the latter text among many other things de Andrade suggests that all the trouble of the human soul that Sigmund Freud writes about, did not exist in Brazil before the encounter - the Europeans imported the concept of shame. This is quite a strong accusation, supported by de Andrade's claim that before the Europeans discovered Brazil, Brazil had discovered happiness (in Manifesto Antropofago, 1928). If we take this as the context of the poem, this short text may be seen as an invitation to think about how different the history of the world could be if a) the encounter would never have happened or b) the more dynamic and aggressive side of the two would have been the Indians.

One more additional layer, an easy object to become lost in translation, comes from the title of the poem. The logical way to translate it so that it fits with the contents of the poem is the way how it is done in the English version given in the footnote: "Mistake of the Portuguese". But the common meaning of the expression "erro de portugues" is a language mistake made in Portuguese a very unpoetical title for a poem. Language errors, or more precisely - the deviations of the Portuguese used in Brazil as opposed to the normative version of Portugal - have also often been the subject of Oswald de Andrade's poetry. These allusions form part of the Brazilian debate about localizing the global and finding original local answers to universal questions under the conditions of constant cultural imperialism coming from the (ex-) colonizers.

The main purpose of this article is to prove that there are new and enriching meanings being born within a "peripheral copy of a central literary movement". The next example I bring is the concept of the so-called "wild man", which is perceived very differently in the contexts of Latin America and Europe.

The concept of the "wild man" was quite central for modernists all over the world. The European modernist artists and poets applied African and Latin American indigenous art in their work and the way they imagined the worldviews of those 'wild men' served them as inspiration. The Guarani Indian and the silly black man from the poem "Brasil" with their funny "ethnic" languages took part in the birth of Modernism without themselves knowing about it.

In the heads of the Europeans of the beginning of the $20^{\text {th }}$ century the image of a 'wild man' was formed as a combination of, firstly, a vague picture of the noble savage of Rousseau's romantic tradition (with the innate goodness as 
the distinguishing feature), and, secondly, a possible first-hand experience or press-mediated account of a meeting with "a specimen" brought to Europe for the curious eyes to look at. A cultured Frenchman could certainly have seen "a wild man" at the World Fair of Paris in 1889 with 400 indigenous persons on display as the major attraction enjoying 28 million visitors over six months, or the colonial exhibition of 1931 including a huge human zoo (33 million visitors). ${ }^{4}$ Both views about the savage - the romantic and the downgrading are certainly strongly detectable in dadaist and surrealist poetry and other modernist core texts that served as examples for the cultural change both in and outside Europe at the time.

When the ideas of modernism reached Brazil, the notion of the 'wild man' seen through the eyes of the European modernists caused great confusion. There was an obvious mismatch between the meanings attached to this term. What counts as exotic for European modernism, signifies roots, history and identity for Latin Americans. Everybody has some Indian and African blood in his veins in Brazil, so it is not so easy to see the indigenous or the African as the Other. The process of othering can take place, of course, but with its innate logic it is quite different from the same process with European subject.

So, there is very strong ambivalence in the Brazilian modernists' attitude towards "primitive". The Indian community and history in Brazil gives reasons for

- pride (of heritage),

- shame (of backwardness),

- problematic reality (poverty)

- a source of inspiration for national identity.

The landing of European modernist ideas in Brazil resulted in a new layer in the image of the indigenous people: they were highlighted by the world trendsetters, the Europeans. From one side the 'wild men' seemed to be respected and idealized, from the other side simplified and downgraded by European modernists. The young Brazilian actors of cultural change, the modernists-tobe had a huge challenge what to make of all this. They came out with highly original literary answers to the set of questions.

\footnotetext{
4 The concept of human zoo became widely popular in many major European cities. The displays usually emphasized the cultural differences between European and non-European peoples. In the informative part of the exhibition a number of them placed indigenous people (particularly Africans) in a continuum somewhere between the great apes and humans of European descent.
} 
PESTI

\section{The hero with no character}

The different perception of the concept of 'wild man' exemplified how the consequences of modernism in Brazil were quite different from that of other places. Sometimes this situation led to even more multi-layered literary works than those that modernism produced in Europe. The best example of all of the arguments made above is a Brazilian modernist novel written by one of the leading modernist authors Mario de Andrade as a joke over six days.

Macunaima (1928) is a novel of an anti-hero struggling between the rain forest and the metropolis, progress and tradition. Macunaima does not follow any Brazilian literary traditions, it uses colloquial language, including obscene expressions, nearly oral syntax and stylisation very close to the fairy tale. There is huge authenticity condensed in the book, it is based on profound research and includes many existing names, phrases, locations and customs so that "every Brasilian has a bit of Macunaíma in him" (Proença 1955: 24). In Macunaima the fusion of popular and erudite codes represents something completely new. It surprised and confused even progressive critics of its time, and was called "a structural fantasy" by critics (Bosi 2003: 195) and "a rhapsody” by its author after great difficulties in naming it (Proença 1955: 7).

The narrative somewhat follows the Holy Grail stories. For Macunaíma the city is no escape from the forest and vice versa, there is the constant pain of no way out. Amazonia is not happy; but the urban badly europeanized and semiamericanized city is no good solution either. The only way out is a cosmic exile: in the last pages the hero turns into a constellation of stars. The author has said that he laughed a lot while writing the book in six days over a vacation but while writing the last pages he started to cry: he does not want the exile to be the only solution! The fate of Brasil seems to have no constant identity (Bosi 2003: 206).

The picture would be very depressive, but the author adds infantile spontaneity, creates the character of Macunaíma according to the tradition of constructing heroes in Amazonian mythology - always stimulated by pleasure or by fear. The difficulty to define the symbolic identity of the hero as a national character comes from crossing perspectives of the author Mario de Andrade:

- a person with a civilizing mission, a modern rational man of letters who satirizes romantic idealization of national ethos; 
- a person with the eye on primitive, archaic, mythopoetic, with a very critical view to the city of progress: he gives an excellent satire of the new rich and their exhibitionist culture in São Paulo.

Mario de Andrade has confessed that he had the desire to be Macunaíma himself (Proença 1955: 33). At the same time he goes against himself writing this book, being afraid to make mistakes in Portuguese, using irony - shortly: primitivizing himself (Candido 1970:8). Thus the complicated inner conflict about positioning the 'wild man' within the modernizing world takes place within the author and within the novel. Brazilian modernists were of course divided and had different political views but this contradiction within their leading figure Mario de Andrade that found its artistic form in Macunaima can be generalized as the spirit of the time. Macunaima becomes the symbol of the main fissure, the hard-to-find recipe of the perfect cocktail of global and local values, the difficult choice of whether to concentrate on roots or new imported values of progress and growth.

The main tone of Macunaima is carried by a constant twitch between nationalist optimism and pessimism, with the latter, darker side, generally prevailing. The optimism came from nationalist or nativist feelings, which were structural in the 19th century, when the new national Latin American formations defined themselves. The history of optimistic nationalism is strongly present in Brazilian literature, mainly in the works of the romanticist novelist José de Alencar and other romantic writers (Bosi 2003: 198-9).

Gradually, as we move along the timeline, the optimistic spirit appears in contrast to the pessimism of social Darwinism and racism, as racist theories started to diffuse strongly at the beginning of the 20th century in Brazil. In addition, during the 20th century there also appears neocolonial pessimism: constant comparisons of advances in Europe and the USA and the backwardness of Brazil. The latter idea is of course produced by the center itself who chooses the norms against which to compare who is forward and who is backward.

\section{Conclusion}

Hopefully this article has its share in proving why at least some of the national versions of international literary movements should be embraced into the universal concept of this movement not just as a fading copy of the original, but as an alternative development of similar ideas in a different context. The Brazilian modernists with their doubts between the values of the rain forest and 
PESTI

those of metropolis, with their struggles to find a balance between them, certainly came up with literary answers different from those of their European counterparts. And that also applies to many other literary movements, their expressions in the center and the alternative expressions elsewhere. The canon of world literature should thus be re-constructed with an awareness of all such alternatives and include them.

\section{References}

Andrade, M. de. 2004. Macunaíma. O herói sem nenhum carater. Belo Horizonte/Rio de Janeiro: Villa Rica Editoras Unidas,

Andrade, O. de. 1924. Manifesto Pau-Brasil. Correio da Manhã 18.03, São Paulo.

Andrade, O. de. 1925. Pau-Brasil. Paris : Au Sans Pareil.

Andrade, O. de 1927. Primeiro Caderno do Aluno de Poesia Oswald de Andrade. São Paulo.

Andrade, O. de 1928. Manifesto Antropofago. Revista de Antropofagia nr 1, São Paulo.

Bosi, A. 2003. O moderno e o Modernista na Literatura Brasileira. - Ceu, Inferno. São Paulo: Duas Cidades/Editora 34.

Brito, M. da Silva 1971. Historia do modernismo brasileiro. Antecedentes da semana de arte moderna. Civilizacao Brasileira. MEC 3. edicão.

Candido, A. 1970. Varios Escritos. São Paulo: Livraria Duas Cidades.

Lotman, J. 2005. On the Semiosphere. (Trans. by W. Clark). - Sign System Studies , 33.1, 2005.

Morse, R. 1954. São Paulo Since Independence: A Cultural Interpretation. - The Hispanic American Historical Review, Vol. 34, No. 4, (Nov., 1954), pp. 419-444. Duke University Press.

Proença, C. 1955. Roteiro de Macunaima. São Paulo: Editora Anhembi.

Schwarz, R. 1992. Misplaced Ideas. Essays on Brazilian Culture. London: Verso. 